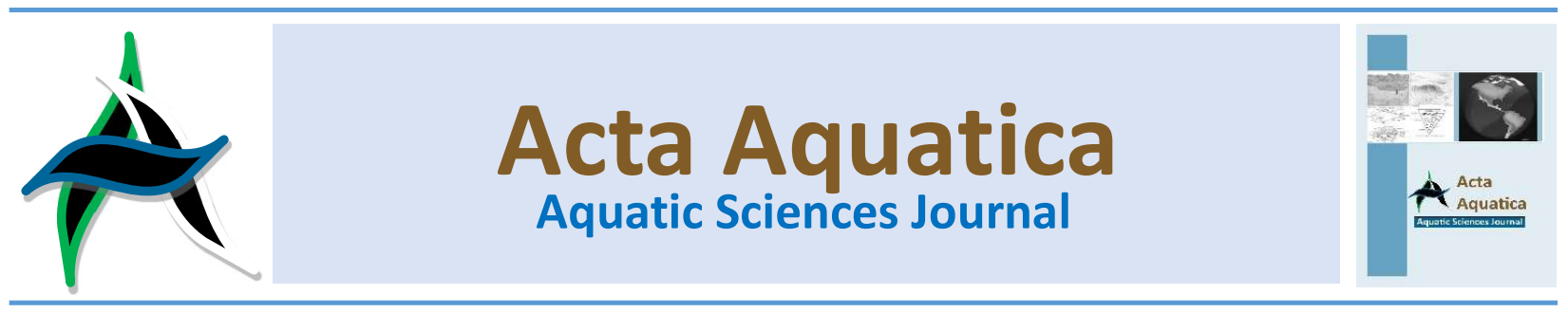

\title{
Respons fisiologis benur udang vaname (Litopenaeus vannamei) terhadap penambahan kalsium selama adaptasi di salinitas rendah
}

\section{Physiological responses of white shrimp seed (Litopenaeus vannamei) to calcium addition during adaptation in low salinity}

\author{
Ferdinand Hukama Taqwa ${ }^{a *}$, Mirna Fitrani ${ }^{\mathrm{a}}$ dan Rudi Purwanto ${ }^{\mathrm{a}}$ \\ a Program Studi Budidaya Perairan, Jurusan Perikanan, Fakultas Pertanian, Universitas Sriwijaya
}

\begin{abstract}
Abstrak
Tujuan penelitian ini ialah menentukan penambahan kalsium yang optimum selama adaptasi benur udang vaname di salinitas rendah sehingga kondisi fisiologis benur udang vaname tetap menunjang kelangsungan hidup dan performa pertumbuhan yang maksimal. Disain penelitian menggunakan Rancangan Acak Lengkap berupa penambahan kalsium di air tawar yang digunakan untuk proses penurunan salinitas media dari $20 \mathrm{~g} \mathrm{~L}^{-1}$ hingga mencapai $0,5 \mathrm{~g} \mathrm{~L}^{-1}$ selama 96 jam, yaitu masing-masing sebanyak $150,200,250,300$ dan $350 \mathrm{mg} \mathrm{L}^{-1}$. Air tawar yang digunakan untuk proses penurunan salinitas mengacu hasil penelitian sebelumnya, yaitu telah ditambahkan natrium dan kalium masing-masing sebanyak $75 \mathrm{mg} \mathrm{L}^{-1}$ dan $50 \mathrm{mg} \mathrm{L}^{-1}$. Hewan uji berupa benur udang vaname $\left(\mathrm{PL}_{15}\right)$ yang telah diadaptasikan di salinitas $20 \mathrm{~g} \mathrm{~L}^{-1}$ selama 5 hari. Hasil penelitian menunjukkan bahwa penambahan kalsium sebanyak $300 \mathrm{mg} \mathrm{L}^{-1} \mathrm{di}$ air tawar yang digunakan untuk proses penurunan salinitas selama 96 jam secara signifikan dapat mempercepat waktu moulting (1360 menit), menekan tingkat stres dan laju metabolisme (glukosa cairan tubuh $169,80 \mathrm{mg} \mathrm{dL}^{-1}$ dan tingkat konsumsi oksigen 0,95 $\mathrm{mg} \mathrm{O}_{2} \mathrm{~g}^{-1} \mathrm{jam}^{-1}$ ), serta menghasilkan kelangsungan hidup benur udang vaname tertinggi (99\%).
\end{abstract}

Kata kunci: adaptasi, fisiologis, kalsium, salinitas rendah, vaname

\section{Pendahuluan}

\subsection{Latar belakang}

Udang vaname termasuk dalam kategori organisme euryhaline yang mempunyai kemampuan bertahan hidup di kisaran salinitas air yang luas (Davis, 2004), sehingga pengembangan teknologi untuk rekayasa lingkungan budidaya dapat dilakukan pada kondisi salinitas perairan yang cukup beragam. Kemampuan toleransi udang vaname yang tinggi terhadap kisaran nilai salinitas yang luas ini merupakan salah satu pemicu peningkatan aktivitas budidaya udang vaname terutama di beberapa negara Asia (Shinn et al. 2018; FAO 2018). Beberapa keunggulan lainnya dari komoditas ini adalah proses produksi

* Korespondensi: PS Budidaya Perairan, Jurusan Perikanan, Fakultas Pertanian, Universitas Sriwijaya, Jl. Raya Palembang-Prabumulih KM 32, Indralaya, Sumatera Selatan, Indonesia.

Tel: +62-711-580059 Fax: +62-711-580267

e-mail: ferdinand@fp.unsri.ac.id

\section{Abstract}

The purpose of this study was to determine the optimum addition of calcium during the adaptation period of white shrimp seed in low salinity media, so the physiological conditions of shrimp still support maximally survival and growth. The research was carried out by using the Completely Randomized Design, i.e., the addition of calcium in freshwater for decreasing water salinity from $20 \mathrm{~g} \mathrm{~L}-1$ to $0.5 \mathrm{~g} \mathrm{~L}-1$ as much as $150,200,250,300$, and $350 \mathrm{mg} \mathrm{L}-1$, respectively. The freshwater used in the salinity reduction process was based on previous research that included sodium and potassium additions of $75 \mathrm{mg} \mathrm{L}-1$ and $50 \mathrm{mg} \mathrm{L}-1$, respectively. The test animal was a white shrimp stadium PL15 that had been acclimated for 5 days to a medium salinity of $20 \mathrm{~g}$ $\mathrm{L}-1$. The results of this study showed that the addition of $300 \mathrm{mg}$ L-1- calcium in freshwater during the adaptation for 96 hours significantly accelerate the achievement of moulting time (1360 minutes), suppress the stress levels and metabolism rate (body fluid glucose of $169.80 \mathrm{mg} \mathrm{L}-1$ and oxygen consumption level of $0.95 \mathrm{mg} \mathrm{O} 2 \mathrm{~g}-1 \mathrm{~h}-1)$, and produce the highest survival rate of white shrimp seed (99\%).

Keywords: adaptation, calcium, low salinity, physiology, white shrimp relatif tahan terhadap penyakit dan resiko kerugian rendah (Nguyen et al. 2021). Udang vaname merupakan salah satu jenis dari golongan udang penaeid yang mampu menyesuaikan diri pada salinitas perairan yang tinggi hingga $50 \mathrm{~g} \mathrm{~L}^{-1}$ dan juga di perairan air tawar terutama pada stadia juvenil hingga dewasa (Pan et al. 2007). Namun, tingkat ketahanan udang vaname terhadap infeksi penyakit Infectious Myonecrosis Virus (IMNV) menjadi lebih rentan apabila dibudidayakan di salinitas lebih rendah dari $30 \mathrm{~g} \mathrm{~L}^{-1}$ (Umiliana et al. 2016) dan tingkat pertumbuhannya lebih lambat di salinitas rendah (Li et al. 2015). Udang vaname termasuk dalam kategori hewan osmoregulator, namun bila terjadi perubahan kondisi salinitas media yang ekstrim maka sejumlah besar porsi energi akan digunakan dalam proses homeostatik internalnya yang berkaitan pengaturan keseimbangan cairan tubuh internal terhadap kondisi eksternal, 
sehingga energi yang tersisa untuk proses maintenance dan pertumbuhan akan lebih rendah (Chong-Robles et al. 2014; Jaffer et al. 2020).

Teknologi budidaya udang vaname di media bersalinitas rendah dan di air tawar terus berkembang dan terintegrasi dengan berbagai komoditas pertanian lainnya (Roy et al. 2010; Mariscal-Lagarda et al. 2014). Di sisi lain, ketersediaan benur udang vaname yang telah adaptif di salinitas rendah merupakan salah satu hal penting yang perlu diperhitungkan dalam produksi benur udang siap tebar di lokasi bersalinitas rendah maupun di air tawar, terutama untuk peningkatan produktivitas lahan marjinal. Studi tentang metode adaptasi penurunan salinitas untuk berbagai stadia udang vaname dari salinitas tinggi hingga rendah telah banyak mengalami modifikasi (Taqwa et al. 2008; Hadi et al. 2018) dan diketahui di salinitas rendah kandungan makro mineral yang dibutuhkan pascalarva udang vaname untuk menunjang kelangsungan hidup dan pertumbuhan secara optimal relatif rendah (Perez-Velazquez et al. 2012). Salah satu makro mineral utama yang dibutuhkan udang untuk menunjang proses moulting selama masa pertumbuhannya ialah kalsium (Li dan Cheng, 2012). Kalsium dibutuhkan dalam jumlah yang cukup banyak oleh udang karena lebih dari $90 \%$ kalsium tubuh akan hilang saat proses ganti kulit (Holdich dan Lowery, 1981), sehingga udang akan menyerap kalsium yang berasal dari makanan dan lingkungannya untuk mengganti kalsium yang hilang tersebut.

Taqwa et al. (2010) menunjukkan penggunaan natrium sebanyak $75 \mathrm{mg} \mathrm{L}^{-1}$ dan kalium sebanyak $50 \mathrm{mg} \mathrm{L}^{-1}$ di air tawar pengencer saat proses adaptasi salinitas media selama 96 jam dari salinitas $20 \mathrm{~g} \mathrm{~L}^{-1}$ ke $0,5 \mathrm{~g} \mathrm{~L}^{-1}$ dapat mempertahankan kelangsungan hidup benur udang vaname sebesar $98 \%$ dan tingkat stres yang lebih rendah. Penelitian lanjutan oleh Taqwa et al. $(2011 ; 2012)$ menunjukkan dengan adanya penambahan kalsium pada air tawar yang digunakan sebagai media pengencer sebanyak $125 \mathrm{mg} \mathrm{L}^{-1}$ selama 4 hari masa adaptasi salinitas tersebut menghasilkan kelangsungan hidup benur udang vaname yang lebih tinggi yaitu $99 \%$, namun penambahan kalsium tersebut belum optimal untuk memacu proses klasifikasi. Oleh sebab itu, penambahan kalsium di media air tawar yang digunakan untuk proses pengenceran salinitas selama masa aklimatisasi 96 jam perlu dikaji lebih lanjut untuk mengetahui penambahan optimal yang dapat memperlancar proses moulting dengan kondisi fisiologis tetap menunjang kelangsungan hidup dan pertumbuhan benur udang vaname di salinitas rendah.

\subsection{Identifikasi Masalah}

Kelangsungan hidup dan pertumbuhan benur udang vaname sangat ditentukan dari kondisi lingkungannya, terutama saat dibudidayakan di salinitas rendah. Ketersediaan mineral penting yang dibutuhkan untuk menunjang proses fisiologis udang secara normal akan semakin terbatas dengan menurunnya salinitas media budidaya. Salah satu mineral penting di perairan yang sangat dibutuhkan golongan krustase untuk proses klasifikasi selama masa pertumbuhannya ialah kalsium. Selain itu kalsium juga berperan sebagai salah satu komponen penyangga kestabilan $\mathrm{pH}$ air (buffer system). Kebutuhan kalsium benur udang vaname saat diadaptasikan di salinitas rendah belum dirumuskan dengan lengkap, karena hingga saat ini metode adaptasi yang dikembangkan sangat bervariasi. Pengembangan metode adaptasi benur udang vaname di salinitas rendah dengan penambahan kalsium yang sesuai merupakan salah satu alternatif solusi yang perlu dikaji dengan berbagai pengujian ilmiah sehingga teknologi tepat guna yang dihasilkan telah diformulasikan dengan baik dan dapat diaplikasikan dengan standar prosedur operasional yang baik dan benar.

\subsection{Tujuan dan manfaat}

Tujuan dari penelitian ini adalah optimasi penambahan kalsium selama proses adaptasi benur udang vaname dari media bersalinitas $20 \mathrm{~g} \mathrm{~L}^{-1} \mathrm{ke} 0,5 \mathrm{~g} \mathrm{~L}^{-1}$, sehingga dapat menunjang kondisi fisiologis yang lebih ideal untuk proses moulting, menekan tingkat stres lebih rendah dan mempertahankan kelangsungan hidup tetap tinggi di akhir proses adaptasi.

\section{Bahan dan Metode}

\subsection{Waktu dan tempat}

Penelitian dilakukan di unit mini hatchery Laboratorium Kolam Percobaan Program Studi Budidaya Perairan, Jurusan Perikanan, Fakultas Pertanian Universitas Sriwijaya.

\subsection{Bahan dan alat penelitian}

Bahan-bahan yang digunakan selama penelitian meliputi $\mathrm{PL}_{15}$ udang vaname, kalsium, kalium, natrium, Artemia sp., EDTA air laut dan air tawar. Alat-alat yang digunakan meliputi akuarium, DO meter, refraktometer, spektrofotometer, termometer, pH meter, spuit suntik, batu aerasi, blower, mortar, timbangan digital, tabung eppendorf, centrifuge, selang aerasi, kran aerasi, kran infus, toples bening, dan spektrofotometer.

\subsection{Rancangan penelitian}

Disain percobaan menggunakan rancangan acak lengkap dengan perlakuan berbagai penambahan kalsium di air tawar yang digunakan untuk pengenceran salinitas media selama proses adaptasi PL udang vaname di salinitas rendah. Aplikasi penambahan kalsium $\left(\mathrm{CaCO}_{3}\right)$ dalam media air tawar pengencer masing-masing sebanyak 150, 200, 250, 300 dan $350 \mathrm{mg} \mathrm{L}^{-1}$ selama masa penurunan salinitas dari $20 \mathrm{~g} \mathrm{~L}^{-1}$ menjadi $0,5 \mathrm{~g} \mathrm{~L}^{-1}$. Lama masa adaptasi selama 4 hari dari stadia udang vaname $\mathrm{PL}_{15}$ hingga $\mathrm{PL}_{19}$ (Taqwa et al. 2012). Pada masing-masing perlakuan sebelumnya telah diberikan penambahan $\mathrm{Na}_{2} \mathrm{CO}_{3}$ sebanyak 75 $\mathrm{mg} \mathrm{L}^{-1}$ dan $\mathrm{K}_{2} \mathrm{CO}_{3}$ sebanyak $50 \mathrm{mg} \mathrm{L}^{-1} \mathrm{di}$ air tawar pengencer salinitas berdasarkan hasil terbaik penelitian Taqwa et al. (2010; 2011).

\subsection{Prosedur penelitian}

\subsubsection{Pemeliharaan Benur Udang Vaname Sebelum Perlakuan}

Benur yang digunakan pada tahap adaptasi adalah $\mathrm{PL}_{15}$. Benur diperoleh dari PT. Central Pertiwi Bahari Lampung (stadia $\mathrm{PL}_{10}$ dengan salinitas $25 \mathrm{mg} \mathrm{L}^{-1}$ ), yang dipelihara hingga menjadi $20 \mathrm{mg} \mathrm{L}^{-1}$ saat $\mathrm{PL}_{15}$. Artemia sp. diberikan secara ad libitum dengan frekuensi 4 kali dalam sehari.

\subsubsection{Adaptasi di Salinitas Rendah dengan Penambahan Kalsium}

Media untuk adaptasi berupa akuarium kaca (ukuran 50 $\mathrm{cm} \times 40 \mathrm{~cm} \times 40 \mathrm{~cm}$ ) beserta instalasi sistem aerasi. Di dalam akuarium terdapat toples plastik yang diberi lubang kecil untuk pengamatan proses moulting selama masa adaptasi. Wadah tempat air tawar yang telah dicampur natrium $\left(\mathrm{Na}_{2} \mathrm{CO}_{3}\right) 75 \mathrm{mg} \mathrm{L}-$ 1 , kalium $\left(\mathrm{K}_{2} \mathrm{CO}_{3}\right) 50 \mathrm{mg} \mathrm{L}^{-1}$ dan kalsium $\left(\mathrm{CaCO}_{3}\right)$ ditempatkan dengan posisi lebih tinggi sehingga air tawar dapat mengalir dengan lancar ke wadah untuk proses adaptasi.

Sebanyak 1,5 $\mathrm{L}$ air dengan salinitas $20 \mathrm{~g} \mathrm{~L}^{-1}$ dimasukkan ke masing-masing akuarium dengan ketinggian air $0,75 \mathrm{~cm}$ dan diberi aerasi level sedang selama 3 hari agar kandungan oksigen terlarut $>6 \mathrm{mg} \mathrm{L}^{-1}$. Air tawar yang digunakan berupa air sumur yang berada di lahan rawa. Benur udang vaname stadia $\mathrm{PL}_{15}$ ditebar sebanyak 95 ekor per akuarium. Salinitas diturunkan dari $20 \mathrm{~g} \mathrm{~L}^{-1}$ menjadi $0,5 \mathrm{~g} \mathrm{~L}^{-1}$ dengan cara pengenceran menggunakan tawar yang telah ditambahkan natrium sebanyak $75 \mathrm{mg} \mathrm{L}^{-1}$, 
kalium sebanyak $50 \mathrm{mg} \mathrm{L}^{-1}$ dan kalsium sesuai dengan perlakuan yang dilakukan secara bertahap dengan pengaturan kran output. Salinitas media adaptasi diturunkan secara bertahap dan kontinu, sehingga salinitas media adaptasi akan menjadi $15 \mathrm{~g} \mathrm{~L}^{-1}$ (24 jam), $10 \mathrm{~g} \mathrm{~L}^{-1}$ (28 jam), $5 \mathrm{~g} \mathrm{~L}^{-1}$ (72 jam) dan terakhir menjadi $0,5 \mathrm{~g} \mathrm{~L}^{-1}$ (96 jam).

\subsubsection{Pengumpulan Data}

Kualitas air yang diukur di awal dan akhir adaptasi meliputi kandungan amonia dan kalsium air. Nilai pH, oksigen terlarut, suhu dan salinitas diukur 2 kali sehari. Pencatatan waktu pencapaian moulting dilakukan dengan melihat benur udang vaname moulting pertama kali secara sempurna. Benur udang vaname yang telah moulting secara sempurna dicatat waktunya. Pengamatan dilakukan dari awal tahap adaptasi sampai akhir tahap adaptasi.

Kadar glukosa cairan tubuh udang diukur sebelum proses adaptasi dan hari ke-5 setelah sebelumnya dipuasakan selama 1 hari setelah akhir masa adaptasi. Pengukuran glukosa cairan tubuh benur udang vaname dilakukan dengan metode whole body melalui penggerusan. Hasil gerusan ditimbang dan dimasukkan ke dalam tabung eppendorf yang telah dilapisi EDTA. Tabung eppendorf disentrifus selama 5 menit dengan kecepatan 10000 g. Cairan tubuh diambil dari bagian supernatant menggunakan spuit suntik dan ditempatkan di tabung eppendorf kosong yang telah dipersiapkan sebelumnya. Metode pengukuran kadar cairan tubuh udang menggunakan kit GODPAP dengan bantuan pembacaan spektrofometer.

Pengukuran tingkat konsumsi oksigen diukur pada hari ke- 5 setelah dipuasakan selama 1 hari. Wadah yang digunakan untuk pengukuran konsumsi oksigen berupa toples plastik warna putih bening yang diisi air sesuai perlakuan hingga penuh dan di bagian penutupnya diberi lubang untuk tempat selang aerasi dan probe DO mater. Selanjutnya sebanyak 10 ekor $\mathrm{PL}_{20}$ udang vaname dari masing-masing perlakuan ditimbang dan dimasukkan ke wadah pengukuran tersebut lalu wadah ditutup dengan rapat. Aerasi dihidupkan hingga nilai pada DO meter stabil dan dicatat sebagai data awal pengamatan. Setelah satu jam kadar oksigen terlarut diukur kembali sebagai data akhir pengamatan. Kelangsungan hidup diamati di akhir adaptasi dengan menghitung jumlah udang yang hidup selama masa adaptasi.

\subsection{Parameter uji}

Peubah kualitas air yang diamati beserta pedoman pengukuran dan analisisnya untuk suhu, salinitas, $\mathrm{pH}$, amonia dan kadar kalsium air berdasarkan APHA (2012). Kadar kalsium cairan tubuh benur udang vaname dilakukan dengan cara penggerusan dan sentrifugasi untuk diambil supernatannya berdasarkan Taqwa at al. (2010). Pengamatan waktu pencapaian moulting dilakukan dengan melihat berapa lama benur udang vaname mencapai moulting secara sempurna untuk tiap individu yang terdapat di dalam toples bening (Taqwa et al. 2011). Pengukuran kadar glukosa cairan tubuh berdasarkan metode O'Connor et al. (2011), kelangsungan hidup benur udang vaname mengacu pada Luo et al. (2013), dan pengukuran tingkat konsumsi oksigen berdasarkan Lukas et al. (2017).

\subsection{Analisis data}

Pengolahan data statistik berupa kadar kalsium cairan tubuh benur udang vaname, pencapaian waktu moulting, kadar glukosa cairan tubuh udang dan kelangsungan huidup. Data yang terkumpul dilakukan uji analisis ragam pada selang kepercayaan $5 \%$. Apabila terdapat perbedaan nyata dilanjutkan dengan uji lanjut Beda Nyata Terkecil (BNT) (Steel dan Torie, 1991). Nilai fisika kimia air dan tingkat konsumsi oksigen dianalisis secara deskriptif.

\section{Hasil dan Pembahasan}

\subsection{Fisika Kimia Air}

Kualitas air merupakan salah satu faktor penting yang berperan dalam produksi udang budidaya karena kesesuaian nilainilai fisika, kimia dan biologi air akan berpengaruh baik secara langsung maupun tidak langsung terhadap kelangsungan hidup, kondisi fisiologis dan biokimia, status kesehatan, pertumbuhan dan produksi budidaya udang (Jaffer et al. 2020; Hukom et al. 2020). Nilai kualitas air hasil pengukuran selama proses adaptasi salinitas disajikan pada Tabel 1 .

Tabel 1

Kisaran nilai fisika kimia air media adaptasi benur udang vaname

\begin{tabular}{ccccccc}
\hline $\begin{array}{c}\text { Penambahan } \\
\text { kalsium } \\
\left(\mathrm{mgL}^{-1}\right)\end{array}$ & $\begin{array}{c}\text { Suhu } \\
\left({ }^{\circ} \mathrm{C}\right)\end{array}$ & $\begin{array}{c}\text { Salinitas } \\
\left(\mathrm{g} \mathrm{L}^{-1}\right)\end{array}$ & $\begin{array}{c}\text { Oksigen } \\
\text { terlarut } \\
\left(\mathrm{mg} \mathrm{L}^{-1}\right)\end{array}$ & $\begin{array}{c}\mathrm{pH} \\
(\mathrm{unit})\end{array}$ & $\begin{array}{c}\text { Amonia } \\
\left(\mathrm{mgL}^{-1}\right)\end{array}$ & $\begin{array}{c}\mathrm{Ca}^{2+} \\
\text { Media } \\
\left(\mathrm{mg} \mathrm{L}^{-1}\right)\end{array}$ \\
\hline \multirow{2}{*}{150} & $26-$ & & $5,22-$ & $7,1-$ & $0,012-$ & $70,31-$ \\
& 29 & $0,5-20$ & 7,65 & 7,6 & 0,019 & 100,31 \\
& $26-$ & & $6,32-$ & $7,1-$ & $0,012-$ & $50,69-$ \\
200 & 29 & $0,5-20$ & 7,66 & 7,6 & 0,018 & 70,46 \\
& $26-$ & & $5,42-$ & $7,1-$ & $0,012-$ & $60,23-$ \\
250 & 29 & $0,5-20$ & 7,56 & 7,7 & 0,019 & 70,85 \\
& $26-$ & & $5,71-$ & $7,1-$ & $0,012-$ & $60,31-$ \\
300 & 29 & $0,5-20$ & 7,58 & 7,6 & 0,020 & 70,23 \\
& $26-$ & & $5,56-$ & $7,1-$ & $0,012-$ & $60,77-$ \\
350 & 29 & $0,5-20$ & 7,44 & 7,7 & 0,028 & 80,31 \\
\hline
\end{tabular}

Berdasarkan Tabel 1 diketahui bahwa pemberian kalsium yang berbeda di media air tawar pengencer saat penurunan salinitas dari $20 \mathrm{~g} \mathrm{~L}^{-1}$ ke $0,5 \mathrm{~g} \mathrm{~L}^{-1}$, untuk nilai suhu, salinitas, $\mathrm{pH}$, oksigen terlarut dan amonia masih berada dalam kisaran yang optimal bagi kehidupan udang vaname. Suhu air secara langsung akan mempengaruhi proses metabolisme udang vaname. Wang et al. (2019) menyatakan udang vaname mempunyai kemampuan pengaturan sel sekretori dan sel epitel di ginjal serta konsentrasi metabolit plasma, sehingga dapat beradaptasi pada kisaran suhu yang luas antara $13^{\circ} \mathrm{C}$ hingga $28^{\circ} \mathrm{C}$. Kisaran suhu yang menunjang kelangsungan hidup dan pertumbuhan udang vaname yaitu antara $26-33^{\circ} \mathrm{C}$ (Wickins dan Lee, 2008) atau antara 23,5-31, $5^{\circ} \mathrm{C}$ (Abdelrahman et al. 2018).

Udang vaname dapat hidup di kisaran salinitas $0,5 \mathrm{~g} \mathrm{~L}^{-1}$ hingga $45 \mathrm{~g} \mathrm{~L}^{-1}$ (Lester dan Pante, 1992), namun tumbuh baik di kisaran salinitas $15 \mathrm{~g} \mathrm{~L}^{-1}$ hingga $25 \mathrm{~g} \mathrm{~L}^{-1}$ (Boyd, 1991). Untuk mempertahankan kelangsungan hidupnya terhadap perubahan salinitas perairan maka benur udang vaname akan berusaha mempertahankan keseimbangan hidromineral tubuh (ChongRobles et al. 2014), yaitu melalui pengaturan osmolaritas cairan tubuh dengan cara meningkatkan absorpsi ion terlarut dari media eksternal melalui insang (Roy et al. 2010). Kandungan oksigen terlarut yang diamati dari hari ke-1 sampai hari ke-4 selama penelitian menunjukkan kisaran nilai yang menunjang pertumbuhan benur udang vaname $\left(5,22-7,66 \mathrm{mg} \mathrm{L}^{-1}\right)$. Supono (2015) menyatakan kadar oksigen terlarut di tambak intensif udang vaname idealnya lebih besar dari $4 \mathrm{mg} \mathrm{L}^{-1}$.

Kisaran nilai $\mathrm{pH}$ yang terukur selama penelitian berkisar $7,0-7,1$. Kisaran nilai $\mathrm{pH}$ yang menunjang kelangsungan hidup udang vaname antara 7,5-8,5 (BSN, 2014). Hasil penelitian ini menunjukkan bahwa kisaran $\mathrm{pH}$ air media selama adaptasi penurunan salinitas benur udang vaname masih dalam batas toleransi untuk mendukung kelangsungan hidup dengan baik. Perairan dengan fluktuasi atau nilai $\mathrm{pH}$ yang ekstrim dapat membuat udang stres, menghambat proses ganti kulit sehingga kelangsungan hidup menjadi rendah (Chakravarty et al. 2016). 
Hasil pengukuran amonia selama masa adaptasi salinitas masih dalam kisaran yang aman untuk kehidupan benur udang vaname, yaitu berkisar antara 0,012-0,028 $\mathrm{mg} \mathrm{L}^{-1}$. BSN (2014) mensyaratkan nilai standar amonia untuk budidaya udang vaname $<0,1 \mathrm{mg} \mathrm{L}^{-1}$. Kadar kalsium media di akhir masa adaptasi menunjukkan nilai yang bervariasi, di mana kadar kalsium media tertinggi terdapat pada media adaptasi dengan penambahan kalsium sebanyak $150 \mathrm{mg} \mathrm{L}^{-1}$. Kondisi ini diduga berkaitan dengan perbedaan waktu moulting benur udang vaname saat proses adaptasi selama 4 hari. Kadar kalsium media yang direkomendasikan untuk budidaya udang vaname adalah $100 \mathrm{mg}$ $\mathrm{L}^{-1}$ (Ferreira et al. 2011).

\subsection{Kadar Kalsium Cairan Tubuh Benur Udang Vaname selama Adaptasi}

Kadar kalsium cairan tubuh benur udang vaname pada awal sebelum proses adaptasi adalah $189,90 \mathrm{mg} \mathrm{L}^{-1}$ dan akhir

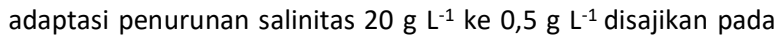
Gambar 1. Penambahan kalsium di media air tawar yang digunakan untuk proses penurunan salinitas menyebabkan perbedaan yang nyata terhadap kadar kalsium tubuh pascalarva udang vaname di akhir masa adaptasi salinitas. Kadar kalsium tubuh benur udang vaname tertinggi terdapat pada perlakuan dengan penambahan kalsium sebanyak $150 \mathrm{mg} \mathrm{L}^{-1}$ yaitu 492,32 $\mathrm{mg} \mathrm{L}^{-1}$ dan terendah pada perlakuan dengan penambahan kalsium sebanyak $250 \mathrm{mg} \mathrm{L}^{-1}$ yaitu sebesar 338,06 $\mathrm{mg} \mathrm{L}^{-1}$. Perbedaan kadar kalsium cairan tubuh benur udang vaname diduga berkaitan dengan beban kerja osmoregulasi dan waktu fase postmoult yang berbeda selama masa adaptasi, sehingga berpengaruh terhadap proses homeostatik dan penyerapan kalsium dari media untuk pembentukan atau pengerasan eksoskeleton.

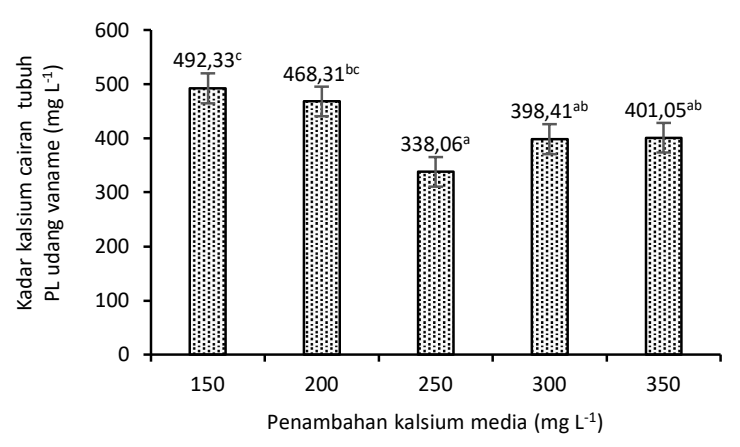

Gambar 1. Kadar kalsium cairan tubuh benur udang vaname di akhir masa adaptasi. Angka dengan huruf superscript yang berbeda menunjukkan perbedaan yang nyata (uji lanjut BNT 5\%).

3.3. Respons Fisiologis dan Kelangsungan Hidup Benur Udang vaname

Kondisi fisiologis benur udang vaname di akhir masa adaptasi penurunan salinitas dari $20 \mathrm{~g} \mathrm{~L}^{-1}$ ke 0,5 $\mathrm{g} \mathrm{L}^{-1}$ selama 96 jam disajikan pada Tabel 2.

Tabel 2

Waktu pencapaian moulting, kadar glukosa, konsumsi oksigen dan kelangsungan hidup benur udang vaname.

\begin{tabular}{ccccc}
\hline $\begin{array}{c}\text { Penambahan } \\
\text { kalsium } \\
\left(\mathrm{mgL}^{-1}\right)\end{array}$ & $\begin{array}{c}\text { Pencapaian } \\
\text { moulting } \\
(\text { menit ke-) }\end{array}$ & $\begin{array}{c}\text { Glukosa } \\
\text { cairan tubuh } \\
\left(\mathrm{mgdL}^{-1}\right)\end{array}$ & $\begin{array}{c}\text { Konsumsi } \\
\text { oksigen }\left(\mathrm{mg} \mathrm{O}_{2}\right. \\
\left.\mathrm{g}^{-1} \text { jam }^{-1}\right)\end{array}$ & $\begin{array}{c}\text { Kelangsungan } \\
\text { hidup (\%) }\end{array}$ \\
\hline 150 & $5200^{\mathrm{d}}$ & $197,90^{\mathrm{e}}$ & 1,77 & 98,00 \\
200 & $4120^{\mathrm{c}}$ & $183,00^{\mathrm{d}}$ & 1,74 & 98,30 \\
250 & $2680^{\mathrm{b}}$ & $177,60^{\mathrm{c}}$ & 1,24 & 99,00 \\
300 & $1360^{\mathrm{a}}$ & $169,80^{\mathrm{b}}$ & 1,11 & 99,30 \\
350 & $4600^{\text {cd }}$ & $163,00^{\mathrm{a}}$ & 0,95 & 97,30 \\
\hline
\end{tabular}

Keterangan angka dengan huruf superscript berbeda pada kolom yang sama menunjukkan perbedaan yang nyata (uji lanjut BNT $5 \%$ ).

Wickins dan Lee (2008) menyatakan bahwa proses moulting udang terdiri dari beberapa fase. Salah satunya ialah fase intermolt awal, yaitu saat udang mengalami homeostatik kalsium untuk menyeimbangkan kalsium tubuh dengan perairan. Selanjutnya fase molt yaitu pengumpulan kalsium di lambung yang berasal dari kulit dan perairan, sedangkan fase postmoult adalah fase pelepasan eksoskeleton dan transpor ion kalsium untuk pembentukan jaringan kulit. Adapun fase intermolt akhir keadaan normal udang di mana ion kalsium terkonsentrasi di hepatopankreas.

Mineral kalsium sangat dibutuhkan oleh udang sebagai komponen utama dalam proses moulting dan pengerasan cangkang, serta untuk menunjang proses osmoregulasi dan fungsi vital lainnya (Zweig et al. 1999). Hasil pengujian menunjukkan bahwa penambahan kalsium berpengaruh nyata terhadap pencapaian waktu moulting. Penambahan kalsium 300 $\mathrm{mg} \mathrm{L}^{-1}$ menyebabkan pencapaian waktu moulting tercepat yaitu 1360 menit, dan pencapaian waktu moulting terlama terdapat pada perlakuan dengan penambahan kalsium $150 \mathrm{mg} \mathrm{L}^{-1}$. Hal ini menunjukkan penambahan kalsium sebanyak $150 \mathrm{mg} \mathrm{L}^{-1}$ belum dapat menciptakan kondisi lingkungan yang mendukung pencapaian waktu moulting yang lebih cepat. Namun apabila penambahan kalsium berlebihan seperti pada perlakuan dengan

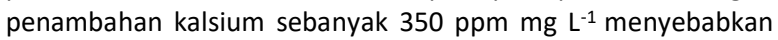
kadar kalsium media yang terlalu tinggi dan benur udang vaname akan mengalami hambatan dalam proses moulting.

Penambahan kalsium dengan besaran yang beragam di media adaptasi menyebabkan respons fisiologis benur udang vaname yang bervariasi di akhir masa adaptasi. Salah satu respons fisiologis yang umum dijadikan sebagai indikator stres ialah dinamika kadar glukosa darah. Kadar glukosa cairan tubuh benur udang vaname yang diukur sebelum adaptasi adalah $131,29 \mathrm{mg} \mathrm{L}^{-1}$. Kadar glukosa benur udang vaname di akhir adaptasi salinitas rendah menunjukkan peningkatan dan signifikan berbeda untuk semua perlakuan. Kadar glukosa cairan tubuh benur udang vaname di akhir masa aklimatisasi masih dalam kisaran nilai yang cukup tinggi, karena pada kondisi normal kadar glukosa darah udang umumnya tidak lebih dari $150 \mathrm{mg} \mathrm{L}^{-1}$ (Cuzon et al. 2004). Peningkatan penambahan kalsium lebih besar dari $150 \mathrm{mg} \mathrm{L}^{-1}$ menunjukkan kecenderungan semakin rendah tingkat stres benur udang vaname di akhir masa adaptasi penurunan salinitas. Hal ini mengindikasikan bahwa penambahan mineral penting (kalsium) dalam jumlah yang tepat dapat menekan tingkat stres benur udang vaname selama masa

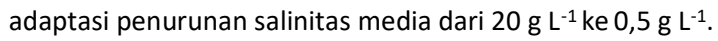

Udang vaname merupakan golongan organisme osmoregulator, yaitu organisme yang mempunyai kemampuan untuk menjaga kemantapan osmolaritas cairan tubuhnya terhadap dinamika lingkungan eksternal. Ketika udang mengalami stres akibat perubahan salinitas maka udang akan menjaga keseimbangan cairan tubuhnya dengan cara melakukan proses osmoregulasi agar metabolisme tubuhnya tidak terganggu. Berbagai studi menunjukkan bahwa mineral yang berperan penting dalam mekanisme osmoregulasi udang di salinitas rendah meliputi natrium, kalium, kalsium dan magnesium (Mantel and Farmer, 1983; Araneda et al. 2008). Penambahan natrium, kalium, magnesium dan kalsium di air tawar pengencer sangat berperan dalam menunjang mekanisme kerja osmotik udang, karena merupakan senyawa penting bagi kerja metabolisme tubuhnya. Mineral penting yang dibutuhkan sel tersebut dibawa melalui transport aktif natrium dan kalium di dalam sel melalui sepasang pompa ion. Proses ini membutuhkan energi yang berasal ATP yaitu melibatkan sistem enzimatik berupa $\mathrm{Na}^{+} \mathrm{K}^{+}$ATPase (Larvor, 1983). Proses pengaturan 
keseimbangan hidromineral tubuh dengan lingkungan eksternal tersebut berjalan seiring dengan proses respirasi (Roy et al. 2010). Oleh sebab itu, kondisi cairan tubuh udang yang isoosmotik terhadap lingkungan akan menunjang proses osmoregulasi dan respirasi yang lebih efisien.

Tingkat konsumsi oksigen merupakan salah satu metode praktis yang umum digunakan untuk mengetahui laju metabolisme benur udang. Rosas et al. (1999) menyatakan konsumsi oksigen udang $L$. setiferus semakin rendah seiring dengan peningkatan salinitas media saat stadia $\mathrm{PL}_{10}$ hingga $\mathrm{PL}_{15}$, namun saat stadia $\mathrm{PL}_{15}$ hingga $\mathrm{PL}_{21}$ terjadi fenomena yang berlawanan. Hal ini menunjukkan penurunan salinitas secara bertahap menghasilkan laju konsumsi oksigen benur udang vaname yang lebih tinggi saat stadia udang vaname lebih muda. Pada pengujian ini terdapat kecenderungan semakin tinggi kalsium yang ditambahkan maka akan semakin rendah tingkat konsumsi oksigen. Hal ini menandakan pada saat terjadi penurunan salinitas secara bertahap, apabila kebutuhan mineral penting selama proses osmoregulasi terpenuhi, maka dapat menunjang laju metabolisme benur udang yang lebih efisien.

Penambahan kalsium selama masa adaptasi penurunan salinitas tidak menyebabkan perbedaan tingkat kelangsungan hidup benur udang vaname yang signifikan di akhir adaptasi salinitas rendah. Secara keseluruhan tingkat kelangsungan hidup benur udang vaname yang dihasilkan masih dalam kisaran yang tinggi (97-99\%). Tingkat kelangsungan hidup tertinggi terdapat pada perlakuan dengan penambahan kalsium sebanyak $300 \mathrm{mg}$ $\mathrm{L}^{-1}$, sedangkan terendah terdapat pada perlakuan dengan penambahan kalsium $150 \mathrm{mg} \mathrm{L}^{-1}$. Kelangsungan hidup benur udang vaname yang dicapai pada penelitian ini masih dalam kisaran nilai yang relatif seragam berdasarkan berbagai pengujian teknik adaptasi benur udang vaname di salinitas rendah oleh Taqwa et al. (2010; 2011; 2012). Namun berdasarkan perbandingan respons fisiologis benur udang vaname di akhir masa adaptasi salinitas dari berbagai metode tersebut dapat dirumuskan jika metode adaptasi dengan penambahan kalsium sebanyak $300 \mathrm{mg} \mathrm{L}^{-1}$ menghasilkan kualitas benur udang vaname siap tebar yang lebih baik di salinitas $0,5 \mathrm{~g}$ $\mathrm{L}^{-1}$.

\section{Kesimpulan}

Berdasarkan hasil penelitian dapat disimpulkan bahwa penambahan kalsium sebanyak $300 \mathrm{mg} \mathrm{L}^{-1}$ di air tawar yang digunakan untuk proses penurunan salinitas menghasilkan kondisi yang lebih menunjang pemenuhan kebutuhan mineral penting untuk osmoregulasi, efisiensi respirasi, pencapaian waktu moulting yang lebih cepat, menekan tingkat stres yang lebih rendah dan tingkat kelangsungan hidup benur vaname yang tinggi di akhir masa adaptasi. Kualitas air selama adaptasi salinitas rendah masih sesuai standar kelayakan budidaya udang vaname.

\section{Bibliografi}

Abdelrahman, H. A., A. Abebe, C.E. Boyd, 2018. Influence of variation in water temperature on survival, growth and yield of Pacific white shrimp Litopenaeus vannamei in inland ponds for low-salinity culture. Aquaculture Research, 50(2): 658-672.

American Public Health Association (APHA), 2012. Standard Methods for the Examination of Water and Wastewater. Washington DC (US): American Public Health Association. 1360 pp.

Araneda, M, E.P. Perez, E. Gasca-Leyva, 2008. White shrimp Penaeus vannamei culture in freshwater at three densities: condition state based on length and weight. Aquaculture, 283(1-4): 13-18.
Badan Standarisasi Nasional (BSN), 2014. SNI 8037.1: Udang Vaname (Litopenaeus vannamei, Boone 1931) Bagian 1: Produksi Induk Model Indoor. BSN Jakarta.

Boyd, C.E., 1991. Water Quality Management and Aeration in Shrimp Farming. Pedoman teknis dan Proyek penelitian dan Pengembangan Perikanan. Jakarta.

Chakravarty M.S, P.R.C. Ganesh , D. Amarnath, B. Shanthi Sudha, T. Srinu Babu, 2016. Spatial variation of water quality parameters of shrimp (Litopenaeus vannamei) culture ponds at Narsapurapupeta, Kajuluru and Kaikavolu villages of East Godavari district, Andhra Pradesh. International Journal of Fisheries and Aquatic Studies, 4(4): 390-395.

Chong-Robles, J., G. Charmantier, V. Boulo, J. Lizárraga-Valdéz, L.M. Enríquez-Paredes, I. Giffard-Mena, 2014. Osmoregulation pattern and salinity tolerance of the white shrimp Litopenaeus vannamei (Boone, 1931) during post-embryonic development. Aquaculture, 422: 261-267.

Cuzon, G., A. Lawrence, G. Gaxiol, C. Rosa and J. Guillaume, 2004. Nutrition of Litopenaeus vannamei reared in tanks or in ponds. Aquaculture, 235: 513-551.

Davis, D.A., T.M. Samocha, C.E. Boyd, 2004. Acclimating Pacific White Shrimp, Litopenaeus vannamei, to Inland, LowSalinity Waters. SRAC Publication No. 2601. 8 p.

Ferreira, N. C., C. Bonetti, W.Q. Seiffert, 2011. Hydrological and water quality indices as management tools in marine shrimp culture. Aquaculture, 318(3-4): 425-433.

Food and Agricultural rganization (FAO), 2018. The State of World Fisheries and Aquaculture 2018 - Meeting The Sustainable Development Goals. (Rome. Licence: CC BY-NC-SA 3.0 IGO).

Hadi, F.R., I. Riyantini, U. Subhan, Y.N. Ihsan, 2018. Efek cekaman salinitas rendah perairan terhadap kemampuan adaptasi udang vaname (Litopenaeus vannamei). Jurnal Perikanan Kelautan, 9(2): 72-79.

Holdich, D.M and R.S Lowery, 1981. Freshwater Crayfish: Biology, Management and Exploitation. Croom Helms, London and Sidney. Timber Press, Portland Oregon.

Hukom, V, R. Nielsen, M. Asmild, M. Nielsen, 2020. Do aquaculture farmers have an incentive to maintain good water quality? The case of small-scale shrimp farming in Indonesia. Ecological Economics, 176: 106717.

Jaffer, Y.D., R. Saraswathy, M. Ishfaq, J. Antony, D.S. Bundela, P.C. Sharma, 2020. Effect of low salinity on the growth and survival of juvenile pacific white shrimp, Penaeus vannamei: A revival. Aquaculture, 515: 734561.

Larvor, P., 1983. Minerals. P 281-315. in: Riis PM. (Eds). Dinamic Biochemistry of Animal Production. Elsevier. Amsterdam.

Lester, L and M.J. Pante.,1992. Penaeid temperature and salinity responses. Developments in Aquaculture and Fisheries Science, 23(24): 515-534.

Li, C. H. and S.Y. Cheng, 2012. Variation of calcium levels in the tissues and hemolymph of Litopenaeus vannamei at various molting stages and salinities. Journal of Crustacean Biology, 32(1): 101-108.

Li, E., X. Wang, K. Chen, C. Xu, J.G. Qin, L. Chen, 2015. Physiological change and nutritional requirement of Pacific white shrimp Litopenaeus vannamei at low salinity. Reviews in Aquaculture, 7: 1-17.

Lukas A. Y. H., D. Djokosetiyanto, T. Budiardi, A.O. Sudrajat, R. Affandi, 2017. Optimization of salinity and calcium on Indonesian shortfin eel Anguilla bicolor maintenance. AACL Bioflux, 10(4): 951-961. 
Luo M., R. Guan, Z. Li, H. Jin, 2013 The effects of water temperature on the survival, feeding, and growth of the juveniles of Anguilla marmorata and A. bicolor pacifica. Aquaculture, 400-401: 61-64.

Mantel, L.H and L.L. Farmer, 1983. Osmotic and lonic Regulation. In:Mantel, L.H. (ed), The Biology of Crustacea. Volume 5, Internal Anatony and Physiological Regulation. Academic Press, New York, USA. pp 54-162.

Mariscal-Lagarda, M.M., F. Paez-Osuna, J.L. Esquer-Méndez, I. Guerrero-Monroy, A.R. Del Vivar, K.Y. Brito-Solano, D.N. Lopez-Perez, R.O.S.A.B.A. Alonso-Rodrãguez, 2014. Water quality in an integrated culture of white shrimp (Litopenaeus vannamei)-tomato (Lycopersicon esculentum) using low salinity groundwater in Sonora, Mexico. Experimental Agriculture, 50(2): 306.

O'Connor, E. A., T.G. Pottinger, L.U. Sneddon. 2011. The effects of acute and chronic hypoxia on cortisol, glucose and lactate concentrations in different populations of three-spined stickleback. Fish Physiology and Biochemistry, 37(3): 461-469.

Pan, L-Q., L-J. Zhang, H. Liu, 2007. Effects of salinity and pH on ion-transport enzyme activities, survival and growth of Litopenaeus vannamei postlarvae. Aquaculture, 273: 711-720.

Perez-Velazquez, M., D.A. Davis, L.A. Roy, M.L. González-Félix, 2012. Effects of water temperature and $\mathrm{Na+:} \mathrm{K}+$ ratio on physiological and production parameters of Litopenaeus vannamei reared in low salinity water. Aquaculture, 342: 13-17.

Rosas, C., L. Ocampo, G. Gaxiola, A. Sánchez, L.A. Soto, 1999. Effect of salinity on survival, growth, and oxygen consumption of postlarvae $\left(\mathrm{PL}_{10}-\mathrm{PL}_{21}\right)$ of Litopenaeus setiferus. Journal of Crustacean Biology, 19(2): 244251.

Roy, L. A., D.A. Davis, I.P. Saoud, C.A. Boyd, H.J. Pine, C.E. Boyd, 2010. Shrimp culture in inland low salinity waters. Reviews in Aquaculture, 2(4): 191-208.

Shinn, A.P., J. Pratoomyot, D. Griffiths, T.Q. Trong, N.T. Vu, P. Jiravanichpaisal, M. Briggs, 2018. Asian shrimp production and the economic costs of disease. Asian Fish. Sci., 31: 29-58.

Steel, R.G.D. and J.H. Torrie, 1991. Principles and Procedures of Statistics. London (UK): McGraw-Hill, Book Company INC. $487 \mathrm{p}$.

Supono., 2015. Manajemen Lingkungan untuk Akuakultur. Plantaxia. Yogyakarta: 114 hal.

Taqwa, F.H., D. Djokosetiyanto, R. Affandi, 2008. Pengaruh penambahan kalium pada masa adaptasi penurunan salinitas terhadap performa pascalarva udang vaname (Litopenaeus vaname). Jurnal Riset Akuakultur, 3(3): 431-436.

Taqwa, F.H., D. Jubaedah, M.I. Mahardika, 2011. Waktu pencapaian moulting, tingkat stres dan sintasan pascalarva udang vaname (Litopenaeus vannamei) selama masa penurunan salinitas dengan penambahan kalsium. Majalah IImiah Sriwijaya, 19(12): 695-702.

Taqwa, F.H., M. Fitrani, B.T. Esto, 2012. Performa Pascalarva Udang Vaname (Litopenaeus vannamei) pada Berbagai Lama Masa Adaptasi Penurunan Salinitas Rendah dengan Penambahan Natrium, Kalium dan Kalsium. Prosiding Seminar Nasional Ke-Il Hasil-Hasil Penelitian Perikanan dan Kelautan. Semarang. 4 Oktober 2012. Hal. 52-58.
Taqwa, F. H., M. Syaifudin, D. Jubaedah, O. Saputra, 2010. Tingkat Stres dan Kelangsungan Hidup Pascalarva Udang Vaname (Litopeneaus vannamei) selama Masa Penurunan Salinitas Rendah dengan Penambahan Natrium dan Kalium. Prosiding Seminar Nasional Hasihasil Penelitian dan Pengkajian. Hasil-hasil Riset untuk Meningkatkan Kesejahteraan Rakyat. Palembang 1314 Desember 2010. Hal. 27-36.

Umiliana, M, Sarjito, Desrina, 2016. Pengaruh salinitas terhadap infeksi Infectious Myonecrosis Virus (IMNV) pada udang vaname Litopenaeus vannamei (Boone, 1931). Journal of Aquaculture Management and Technology, 5(1): 7381.

Van Nguyen, C., J. Schwabe, M. Hassler, 2021. White shrimp production systems in central Vietnam: Status and sustainability issues. Egyptian Journal of Aquatic Biology and Fisheries, 25(1): 111-122.

Wang, Z., Y. Qu, M. Yan, J. Li, J. Zou, L. Fan, 2019. Physiological responses of Pacific white shrimp Litopenaeus vannamei to temperature fluctuation in low-salinity water. Frontiers in physiology, 10: 1025.

Wickins, J and D.O.C. Lee, 2002. Crustacean Farming Ranching and Culture. 2nd edition. Blackweel science. London. P 16-17.

Zweig, R. D., J.D Morton, M.M. Stewart, 1999. Source Water Quality for Aquaculture: A Guide for Assessment. The World Bank. 